\title{
COMMON CARRIER, COMMON PURCHASER AND COMMON PROCESSOR ORDERS
}

\author{
C. H. HEBB*
}

This article presents an analysis of the provisions of the Alberta Oil and Gas Conservation Act with respect to common carrier, common purchaser and common processor applications, considers their relationship to other statutory provisions, and discusses some representative applications. With respect to the objectives of a conservation statute, this article concludes that provisions for common carrier, common purchaser and common processor orders are based on the objective of protection of correlative rights, rather than on the objective of prevention of waste.

\section{A. INTRODUCTION}

This article will deal with common carrier, common purchaser and common processor procedures in Alberta with a view to establishing the extent to which the underlying philosophy of conservation is considered. The article will examine the following: firstly, the applicable legislation and regulations, secondly, the advantages of the procedures and their relation to other statutory provisions, thirdly, some representative applications, and fourthly, the procedures as related to the doctrine of correlative rights and the purpose and intent of the Alberta Oil and Gas Conservation Act.

\section{B. STATUTES AND REGULATIONS}

Section 42 of the Alberta Oil and Gas Conservation Act provides that the Oil and Gas Conservation Board, with the approval of the Lieutenant Governor in Council, may designate a proprietor of a pipe line to be a common carrier. ${ }^{1}$ This section further provides that upon being declared a common carrier, no proprietor shall discriminate as between any of the persons for whom any oil, gas or synthetic crude oil is gathered, transported, handled or delivered by means of a pipe line, nor shall he discriminate in favour of his own products.

Section 43 provides that the Board, with the approval of the Lieutenant Governor in Council, may declare any person who purchases, produces or otherwise acquires oil to be a common purchaser of oil from the pool or pools, as designated by the Board, from which oil is being

* Solicitor, Banff Oil Ltd., Calgary, Alberta.

1 The procedural requirements for an application for a common carrier are set forth in Reg. 1400, as follows:

An application under section 42 of the Act for a declaration that the proprietor of a pipe line is a common carrier shall include

(a) a map showing the location of the pipe line, any alternative pipe lines and the applicant's production facilities, and

(b) discussion of

(i) the details of the supply of oil, oil sands oil or gas, as the case may be. which would be transported in the proposed common carrier operation, and

(ii) the avallable capacity of the pipe line of the proposed common carrier and the practicability of the proposed operation, and

(iii) the economics of alternatives to the proposed common carrier operation, and

(iv) the avallability or the reasonable expectation of a market for the oil, oll sands oll or gas, which would be transported in the common carrier operation. 
taken at the time of the declaration." A common purchaser must purchase oil offered for sale to him without discrimination in favour of one producer or owner as against another in the same pool. ${ }^{3}$ Section $43 a$ contains similar provisions for a common purchaser of gas, but continues as follows, namely:

(4) Upon the application of a common purchaser of gas or of a person who offers gas for sale to a common purchaser of gas and who claims the common purchaser has discriminated against him contrary to this section in purchasing gas, the Board, to assist in giving effect to a declaration under subsection (1), may direct

(a) the point at which the common purchaser shall take delivery of any gas offered for sale to him, or

(b) the proportion of the common purchaser's acquisitions of gas from the pool which he shall purchase from each producer or owner offering gas for sale to him

(5) A direction by the Board under subsection (4) does not operate to require a common purchaser

(a) to purchase a greater total amount of gas from the pool than he was obligated to purchase from the pool under the gas purchase contracts existing immediately before the making of the declaration under subsection (1), or

(b) to purchase gas from the pool at a greater rate than the rate at which he was obligated to purchase gas from the pool under the gas purchase contracts existing immediately before the making of such declaration.

Section 48 provides that the Board, with the approval of the Lieutenant Governor in Council, may declare the owner or operator of a gas processing plant to be a common processor of gas and thereby require such owner or operator to process gas offered to him for processing without discrimination in favour of one producer or owner of gas as against another in the pool or pools. Pursuant to the provisions of Section 48a, the Board may relieve a common processor from processing gas of inferior or different quality or grade.

\section{ADVANTAGES AND RELATION TO OTHER STATUTES}

\section{Common Carrier Applications}

A common carrier application would be appropriate when a producer of oil or gas is unable to negotiate an agreement with a pipeline proprietor for the transporting of the producer's oil or gas. In almost all cases an agreement has been reached between the producer and the pipeline proprietor. Thus the writer is informed that there has been

2 The procedural requirements for an application for a common purchaser are set forth in Reg. 1401, as follows:

An application under section 43 or $43 a$ of the Act for a declaration that a person is a common purchaser of oil or gas shall include

(a) a map showing the areas in which the proposed common purchaser purchases oil or gas and the location of the applicant's property, and

(b) documents showing

(1) that the said person purchases, produces, or otherwise acquires oil or gas, as the case may be, from the pool containing the applicant's property. and

(ii) the opportunities that have existed for the marketing of oil or gas produced from the applicant's property, and

(c) discussion of

(i) the extent that drainage has occurred from the applicant's property subsequently to the completion of a well thereon, and

(ii) the future prospects for marketing the oil or gas.

3 Sec. 44 provides that the Board may relieve a common purchaser from his duty of of purchasing oil or gas of inferior or different quality or grade or from such other duties as in its opinion are unreasonable. 
only one common carrier application in Alberta in the last two decades. The advantage of such an application and its relation to other statutes is as follows:

(a) The pipeline proprietor, as a result of the declaration of common carrier, is forbidden to discriminate between any of the persons for whom any oil or gas is gathered, transported, handled or delivered.

(b) An application may be made by the producer of oil to the Public Utilities Board for an order setting the rates to apply for the gathering, transporting, distributing, handling and delivery of oil."

(c) An application may be made by the producer of gas to the Public Utilities Board for an order setting the rates to apply for the gathering, transporting, distributing, handling and delivery of gas. ${ }^{5}$

The effect of the legislation is that a producer of oil concerned only with the setting of the rates for the transport of oil must first apply to the Oil and Gas Conservation Board to have a proprietor of an oil pipeline declared a common carrier before the producer can apply to the Public Utilities Board to have the rates set. However, a producer of gas concerned only with the setting of the rates for the transport of gas may go directly to the Public Utilities Board to have the rates set for the proprietor of a gas pipeline without first having the proprietor of the gas pipeline declared a common carrier.

\section{Common Purchaser Applications}

A common purchaser application would be appropriate when a producer of oil or gas is unable to negotiate an agreement with a buyer who is purchasing oil or gas in the area. In almost all cases an arrangement has been reached between the producer and the buyer. Thus, the writer is informed that there have been only five common purchaser applications in Alberta. The advantage of such an application and its relation to other statutes is as follows:

(a) The common purchaser, as a result of the declaration, is forbidden to discriminate between the producers of the pool.

(b) An application may be made by the producer of gas to the Public Utilities Board for an order setting the rates to apply for the

4 Sec. 2 (j) (iv) of the Public Utilities Act, S.A. 1960, c. 85, defines a public utility as any oil pipe line declared to be a common carrier by the Oil and Gas Conservation Board. The jurisdiction of the Public Utilities Board with respect to the setting of rates for oil pipe lines is contained in Sec. 101 of the Public Utilities Act, as follows: The Board, after notice to and hearing of the parties interested, may fix the just and reasonable rates, tolls and charges for the gathering, transporting, distributing. handling and delivery of oil or any specifled kind thereof by means of any oil pipe line, or for any service performed by the proprietor of the oil pipe line in relation to the gathering. transporting, distributing. handling or delivery of any oil.

5 Sec. $2(f)$ (i) of the Gas Utilities Act, S.A. 1960, c. 37, defines a gas utility, inter alia, as any gas pipe line. The jurisdiction of the Public Utilities Board with respect to the setting of rates for gas pipe lines is contained in Sec. 27 (a) of the Gas Utilities Act as follows:

The Board, either upon its own initiative or upon complaint in writing, may by order in writing, which shall be made after giving notice to and hearing the parties interested,

(a) fix just and reasonable individual rates, joint rates, tolls or charges or schedules thereof as well as commutation and other special rates, which shall be imposed. observed and followed thereafter by the owner of the gas utility. 
common purchase. ${ }^{6}$ (No similar provision exists with respect to the field price of oil.)

\section{Common Processor Applications}

A common processor application would be appropriate when a producer of gas is unable to negotiate an agreement with a processor who has the processing facilities in the area. The writer is informed that to date, no application for a common processor has been made in Alberta. The advantage of such an application and its relation to other statutes is as follows:

(a) The common processor as a result of the declaration is forbidden to discriminate between producers of gas in the pool or pools.

(b) An application may be made by the producer of gas to the Public Utilities Board for an order setting the rates for the processing of the gas. ${ }^{i}$

\section{SPECIFIC APPLICATIONS}

The only recent common carrier application was made by Prairie Utility Management Ltd., for an order declaring Cretaceous Pipelines Ltd., to be a common carrier of dry residue gas produced from the Willingdon Field. In that application Prairie Utility Management Ltd., was applying to have Cretaceous Pipelines Ltd., declared a common carrier of Prairie's gas produced from the Willingdon Field to be carried to the towns of Hairy Hill and Two Hills with a tie-in to a line to serve the community of Willingdon. Cretaceous had been using its 19-mile line almost exclusively for the transport of natural gas from the Willingdon Field to a chemical plant at Duvernay where the gas was used to produce electricity. The order making Cretaceous Pipelines Ltd. a common carrier of gas produced from the Willingdon Field and the Hairy Hill Field was granted in January, 1963.

a The jurisdiction of the Public Utilities Board to set the field price of gas is contained in Sec. 6(1)(a) (i) of the Gas Utilities Act, Supra, as follows:

Notwithstanding the terms of any contract, the Board upon the application of an interested party or municipality or upon its own motion may, and upon an order of the Lleutenant Governor in Council shall, fix and determine the just and reasonable price or prices to be paid for gas in any or all of the following cases. that is to say:

(a) the just and reasonable price or prices to be paid for gas

(i) in its natural state as and when produced from the earth at the gas exit from the separator, where a separator is employed, and in all other cases as and when produced from the well-head either alone or in association or conjunction with other petroleum products or hydrocarbons.

I Sec. 2(a) of the Gas Utilities Act, Supra, defines an absorption plant as follows: "absorption plant" means any plant for treating or processing gas by absorption or otherwise for the extraction therefrom of natural gasoline or other hydrocarbons. The jurisdiction of the Public Utilities Board with respect to the setting of rates for an absorption plant is contained in Sec. 6(1)(b) of the Gas Utilities Act, Supra, which provides as follows:

Notwithstanding the terms of any contract, the Board upon the application of an interested party or municipality or upon its own motion may, and upon an order of the Lleutenant Governor in Councll shall, fix and determine the just and reasonable price or prices to be paid for gas in any or all of the following cases, that is to say:

(b) the just and reasonable price or prices to be paid for gas that has been gathered and delivered to an absorption plant and after it has been subjected to treating or processing by absorption or otherwise, for the extraction therefrom of natural gasoline or other hydrocarbons.

Sec. $2(j)$ of the Gas Utilities Act, Supra, defines a scubbing plant as follows: "scrubbing plant" means any plant for the purifying, scrubbing or otherwise treating, of gas for the extraction or removal therefrom of hydrogen sulphide or other deleterious substances.

The jurisdiction of the Public Utilities Board with respect to the setting of rates for a scrubbing plant is set out in Sec. 15 of the Gas Utilities Act, Supra. 
In making the application Prairie set forth to accomplish several points:

Now, in these circumstances, where we are making application to have the proprietor of this pipeline declared a common carrier, what must we show the Board? I submit that we must demonstrate to the Board four things.

(1) That we have committed an adequate source of supply of natural gas,

(2) That there is an existing market,

(3) That the applicant has endeavoured, without success, to negotiate with the proprietors of the pipeline for the use of its pipeline, and

(4) That having regard to the failure of these negotiations the objects of the Oil and Gas Conservation Board will best be served if an order is made declaring Cretaceous Pipelines Ltd. to be a common carrier.8

It is interesting to compare these points with those contained in Regulation 1400 setting out what a common carrier application must include. ${ }^{9}$ Points (1) and (2) of Prairie's submission are covered by Points (i) and (iv) of Regulation 1400. Point (3) of Prairie's submission is relevant, but presumably not essential to the Board. The Board now states that the applicant must present the information as to the capacity of the pipeline.

Owing to the difficulty of trying to relate the granting of a common carrier order to all of the objects of the Act, the Board has limited such a discussion to the economics of alternatives to the proposed common carrier operation. It is submitted that this is an acknowledgment that the application relates only to the doctrine of correlative rights and to Section 4 (d) of the Act affording each owner the opportunity of obtaining his just and equitable share of the production of any pool.

The first application under Section 43 of the Act for a common purchaser declaration was submitted by Murphy Oil Company Ltd. and related to a spacing unit in the Carstairs Field. Although drainage from the spacing unit was established, the evidence submitted indicated that on two occasions the applicant had been tendered a gas sales contract covering the spacing unit but had refused to dedicate the underlying reserves. The Board refused Murphy Oil's application and stated its reasons as follows:

In dealing with an application under Section 43 the Board believes that consideration should be given to

(a) whether or not, and if so to what extent, drainage has occurred subsequently to the completion of a well on the applicant's property;

(b) whether or not opportunities have existed for the marketing of gas from the applicant's property and if so, when and the nature of them; and

(c) the prospects for marketing the gas in the near future.

Where no marketing opportunities have existed and where the prospects for marketing without the common purchaser declaration are not favorable, the Board would be sympathetic to an application made even at a time when a relatively small percentage of the reserves has been drained from the property. On the other hand, where marketing opportunities have recently existed, and where there are reasonable prospects for the marketing of the gas in the near future without the common purchaser declaration, the Board will be reluctant to make the declaration unless the drainage is more serious. ${ }^{10}$

The second application under Section $43^{\circ}$ of the Act was submitted by McAlester Canadian Oil Company on behalf of itself and Arrowhead Exploration Company Ltd. and related to a pooled spacing unit in the

s Prairie Utility Management Ltd., Application to the Oil and Gas Conservation Board. September, 1962, Hearing No. 215, Vol. II, p. 35-36.

i Supra., n. 1.

10 Letter dated May 7, 1962 from the Oil and Gas Conservation Board to all Operators. 
Gilby Field. The evidence introduced established that the economic loss from the date that the well was completed to the date that production could be marketed amounted to $\$ 77,500.00$. Trans Canada Pipe Lines had tendered a contract for the purchase of gas from McAlester effective November 1, 1963. McAlester Canadian Oil indicated that the contract was unacceptable due to the low reserves allocated in the spacing unit and due to the fact that deliveries were not to commence until November 1, 1963. Evidence was also submitted showing that the Seaboard Group well was producing $85 \%$ of the total contract volume of the Seabord Group for the entire Gilby area whereas only $20 \%$ of its total contract reserves were attributable to the spacing unit on which the well was situated, and that the British American offset well was producing $100 \%$ of the total contract volume of British American for the Gilby area whereas only $26 \%$ of its total contract reserves were attributable to the spacing unit on which the well was situated. The Board obviously inferred from the evidence of McAlester Canadian Oil that the production from the two wells was responsible for the magnitude of drainage which had occurred. Also, there was no evidence of a prior opportunity to market McAlester's gas. Accordingly, the Board granted the order in July, 1962. It is clear from an examination of these two situations that the Board has followed the guidelines set forth in the current Regulation 1401 for several years in previous applications, and that the probable success or failure of any proposed application can be assessed from an examination of the elements set out in Regulation 1401.

E. COMMON CARRIER, COMMON PURCHASER AND COMMON PROCESSOR PROCEDURES AS RELATED TO THE DOCTRINE OF CORRELATIVE RIGHTS AND THE PURPOSE AND INTENT OF THE ALBERTA CONSERVATION ACT

The doctrine of correlative rights assures every person an opportunity to secure a fair share of the oil or gas beneath his land.

The usual explanation given by the courts in enjoining such wasteful conduct is that each landowner has correlative rights at common law in the oil and gas or in the producing formation and that wasteful conduct of one landowner which injures the correlative rights of another may be enjoined.

It appears quite doubtful that any claim may effectively be asserted under the common law by a landowner that a particular use of oil or gas by another landowner producing from the same formation is a relatively uneconomic use and should be enjoined. So long as the landowner whose conduct is complained of is making some use of the product produced, the courts apparently will not attempt to evaluate the comparative values of alternative use of the product and bar relatively uneconomic use of the product. ${ }^{11}$

Professor Kuntz has suggested that:

The correlative rights of owners in a common source of supply include:

(1) the right against waste of extracted substances,

(2) the right against spoilage of the common source of supply,

(3) the right against malicious depletion of the common source of supply,

(4) the right to a fair opportunity to extract oil and gas. ${ }^{12}$

Professor Kulp related the doctrine to the rule of capture by stating:

While this theory makes inroads on the rule of capture, it does not mean that each landowner is guaranteed his share of the oil and gas, but only that each one is to be given a fair opportunity to capture a reasonable share. He may

11 Williams and Meyers, Oil and Gas Law, Vol. I, at 55-57.

12 Kuntz, Correlative Rights in Oil and Gas, 30 Miss. L.J. 1 (1958). 
still lose through drainage, for he cannot sit idly by and expect to share in another's production. ${ }^{13}$

The incorporation of common carrier, common purchaser and common processor procedures is an incorporation of the doctrine of correlative rights into the administration of oil and gas production. Professor Kulp considered the problem more generally in the following manner:

While conservation statutes were at first enacted as a protection to the public, and the protection of those interested in a given field or pool was only incidental, this was in large part due to the original concept of the right or rule of capture. But graaually the theory of correlative rights, which assures every person an opportunity to secure a fair share of the oil or gas beneath his land, came to be recognized. The conservation laws were amended with that end in view, and this recognition has naturally been reflected more and more in the administration of such laws. ${ }^{1 *}$

The protection provided by the doctrine of correlative rights is usually directly related to the land as in the case of Corzelius v. Harrell. ${ }^{15}$ In that case the Supreme Court of Texas gave protection to an owner who held the vast majority of a field and had set up a recycling plant in which he extracted the liquid hydrocarbons from the gas and then returned the dry gas through two injection wells in the centre of the field. The defendant had acquired a small tract in the field and was taking the gas production directly to market thus taking advantage of the plaintiff by reason of the plaintiff's recycling operations.

The unique extension inherent in the common carrier, common purchaser and common processor procedures is that they are an extension of the doctrine of correlative rights beyond the land itself. The concept of giving an opportunity to every person to secure a fair share of the oil or gas beneath his land has been extended to include the opportunity to have his oil or gas transported, purchased or processed. Thus, producers from different pools may apply to have the owner of the facility declared a common carrier or processor who is forbidden to discriminate between production from different pools. The opportunity for every person to secure a fair share of the oil or gas beneath his land is effectively correlated with all other producers in the Province of Alberta.

In assessing the nature of common carrier, common purchaser and common processor procedures in relation to the intent and purpose of the Act one must refer to Section 4 of the Oil and Gas Conservation Act:

The intent and purpose of this Act are

(a) to effect the conservation of the oil and gas resources of the Province,

(b) to prevent the waste of the oil and gas resources of the Province,

(c) to secure the observance of safe and efficient practices in the locating, spacing, drilling, equipping, completing, reworking, testing, operating and abandonment of wells and in all operations for the production of oil and gas, and

(d) to afford to each owner the opportunity of obtaining his just and equitable share of the production of any pool.

It is clear that the above described procedures are not directly related to Section 4 (a), the conservation of oil and gas resources. It is hard to conceive of any case where these procedures would involve a prevention of waste of oil and gas resources. Almost exclusively the procedures relate to the expanded concept of each owner having an opportunity of obtaining his just and equitable share of the production of any pool.1.

\footnotetext{
13 Kulp, Oil and Gas Rights 516 (1954).

14 Id., at 726

15186 S.W. (2d) 961 (1945).

16 See also Sec. 59 of the National Energy Board Act, S.C. 1959, c. 46.
} 